\title{
Dihydrogen Activation by a Diruthenium Analogue of the Fe-Only Hydrogenase Active Site
}

\author{
Aaron K. Justice, Rachel C. Linck, Thomas B. Rauchfuss, ${ }^{*}$ and Scott R. Wilson \\ Department of Chemistry, University of Illinois at Urbana-Champaign, 600 S. Mathews Avenue, \\ Urbana, Illinois 61801
}

Received July 23, 2004; E-mail: rauchfuz@uiuc.edu

Hydrogenases, enzymes that have been recognized since the 1930s, have come into sharp focus because the unusual nature of their active sites imply mechanistically unusual pathways. ${ }^{1,2}$ The blossoming molecular biology of the hydrogenases coincides with intense research on dihydrogen ligands ${ }^{3}$ augmented by the topicality of the "hydrogen economy". ${ }^{4}$ The $\mathrm{Fe}$-only hydrogenases have received particular recent attention because their active site structure ${ }^{5,6}$ (Figure 1), which resembles the iconic $\mathrm{Fe}_{2}(\mathrm{SR})_{2}(\mathrm{CO})_{6}$, is amenable to synthetic modeling. A particular challenge to modeling is the distal iron, where proton reduction is proposed to occur via a terminal hydrido intermediate.

The diiron site has been studied extensively by synthetic modeling and theoretical experiments. ${ }^{1}$ Models with bridging hydride ligands can been prepared via the protonation of the $\mathrm{Fe}^{\mathrm{I}}-$ $\mathrm{Fe}^{\mathrm{I}}$ bond in $\left[\mathrm{Fe}_{2}(\mathrm{SR})_{2}(\mathrm{CO})_{4} \mathrm{~L}_{2}\right]^{z}\left(\mathrm{~L}_{2}=\left(\mathrm{PMe}_{3}\right)_{2}, \mathrm{z}=0 ; \mathrm{L}_{2}=\right.$ $\left.\left(\mathrm{PMe}_{3}\right)(\mathrm{CN}), \mathrm{z}=1-\right)^{7,8}$ Although the resulting hydrides $\left[\mathrm{Fe}_{2}(\mathrm{SR})_{2^{-}}\right.$ $\left.(\mu-\mathrm{H})(\mathrm{CO})_{4} \mathrm{~L}_{2}\right]^{(z+1)+}$ appear not to adopt biologically relevant stereochemistry, they efficiently catalyze the reduction of protons to dihydrogen. ${ }^{7,9}$ Interaction between diiron dithiolates and $\mathrm{H}_{2}$ is further implicated in the photochemical $\mathrm{H}_{2} / \mathrm{D}_{2} \mathrm{O}$ exchange catalyzed by $\left[\mathrm{Fe}_{2}\left(\mathrm{~S}_{2} \mathrm{C}_{3} \mathrm{H}_{6}\right)(\mu-\mathrm{X})(\mathrm{CO})_{4}\left(\mathrm{PMe}_{3}\right)_{2}\right]^{+}(\mathrm{X}=\mathrm{H}, \mathrm{SMe}){ }^{8,10}$ Despite these advances, no models with terminal hydride or dihydrogen ligands have been produced. We have begun to investigate this and related challenges through studies on diruthenium systems of the type $\mathrm{Ru}_{2}\left(\mathrm{~S}_{2} \mathrm{C}_{3} \mathrm{H}_{6}\right)(\mathrm{CO})_{4}\left(\mathrm{PR}_{3}\right)_{2}{ }^{11,12}$ Experiments described below demonstrate that such diruthenium dithiolates oxidatively add $\mathrm{H}_{2}$ and that the resulting dihydrido species can be protonated to form a dihydrogen complex. Binuclear dihydrogen complexes are rare. ${ }^{3,13}$

We chose to examine the photohydrogenation of $\mathrm{Ru}_{2}\left(\mathrm{~S}_{2} \mathrm{C}_{3} \mathrm{H}_{6}\right)$ $(\mathrm{CO})_{4}\left(\mathrm{PCy}_{3}\right)_{2}\left(\mathbf{1}, \mathrm{Cy}=\mathrm{C}_{6} \mathrm{H}_{11}\right)$. As in previous studies on related diiron dithiolates, phosphine ligands were deployed to simulate the electronic role of the cyanide donor ligands found in the enzyme. ${ }^{31} \mathrm{P}$ NMR studies show that $\mathbf{1}$ is dynamic in solution at room temperature apparently resulting from the rapid interconversion of two rotamers, although this detail is the topic of continuing studies. UV-photolysis of toluene solutions of $\mathbf{1}$ under a flowing atmosphere of $\mathrm{H}_{2}$ gave the dihydride $\mathrm{Ru}_{2}\left(\mathrm{~S}_{2} \mathrm{C}_{3} \mathrm{H}_{6}\right)(\mu-\mathrm{H})(\mathrm{H})(\mathrm{CO})_{3}\left(\mathrm{PCy}_{3}\right)_{2}(2)$, Scheme 1. The ${ }^{1} \mathrm{H}$ NMR spectrum of 2 exhibits well-resolved signals for the bridging and the terminal hydride ligands, coupled to two and one ${ }^{31} \mathrm{P}$ centers, respectively. The ${ }^{31} \mathrm{P}$ NMR spectrum shows that the phosphine ligands are nonequivalent. Crystallographic characterization supports the NMR data, revealing that the phosphine ligands have moved from diaxial positions in $\mathbf{1}$ to mutually trans basal positions in dihydride 2 (Figure 2). The isomerization is perhaps driven by steric interactions between the dithiolate backbone and the axial ligand sites; such interactions would be aggravated by opening of the RuSRu angles, which accompanies the oxidative addition. Spectroscopic measurements indicate that the ethanedithiolate $\mathrm{Ru}_{2}\left(\mathrm{~S}_{2} \mathrm{C}_{2} \mathrm{H}_{4}\right)(\mathrm{CO})_{4}\left(\mathrm{PCy}_{3}\right)_{2}$ also adds $\mathrm{H}_{2}$ similarly. The mutually trans stereochemistry of the hydride

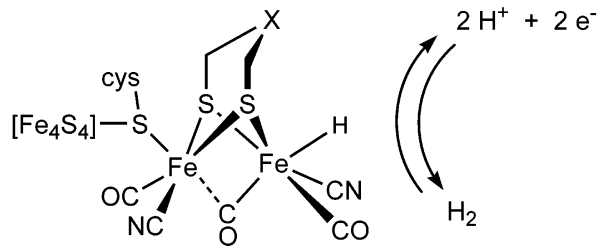

Figure 1. Proposed active site $\left(\mathrm{H}_{\mathrm{red}}\right.$ state) of the Fe-only hydrogenase enzyme based on crystallographic analyses. ${ }^{1} \mathrm{X}$ is assumed to be $\mathrm{NH}_{n}$ but could also be $\mathrm{CH}_{2}$ or $\mathrm{O}^{6}$
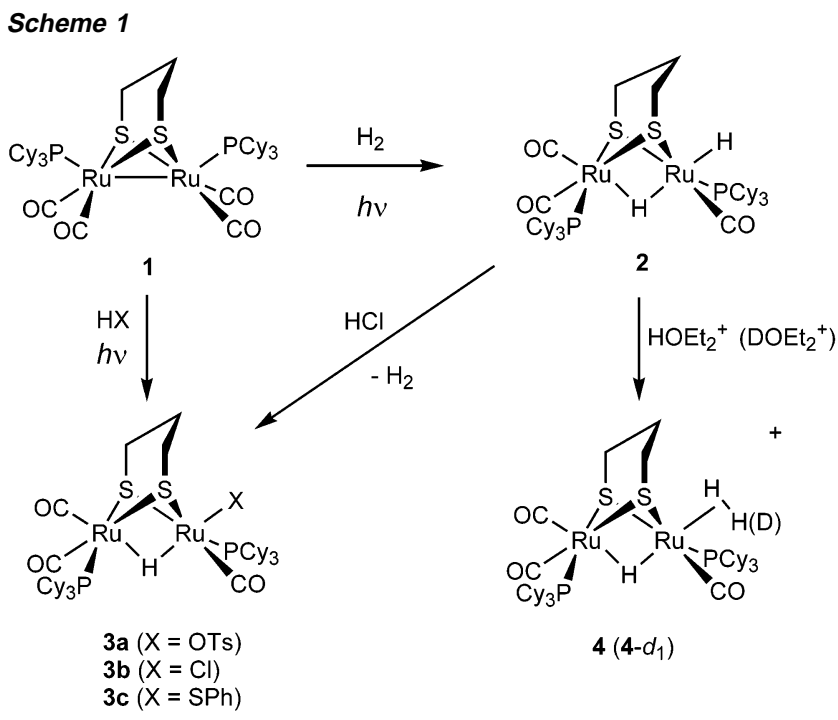

ligands is proposed to arise intramolecularly from an initially formed cis-dihydride via a pathway akin to the isomerization of $\left[\left(\mathrm{C}_{5} \mathrm{H}_{5}\right)\right.$ $\left.\mathrm{Ru}\left(\mathrm{PR}_{3}\right)_{2}\left(\mathrm{H}_{2}\right)\right]^{+}$into trans- $\left[\left(\mathrm{C}_{5} \mathrm{H}_{5}\right) \mathrm{Ru}\left(\mathrm{PR}_{3}\right)_{2}(\mathrm{H})_{2}\right]^{+} .{ }^{14}$ In solution, 2 does not exchange with $\mathrm{D}_{2} \mathrm{O}$ or $\mathrm{D}_{2}$. The $\mathrm{Ru}-\mathrm{Ru}$ distance increases by a substantial $0.2 \AA$ from $2.6875(8)$ to $2.8970(9)$, whereas protonation of the $\mathrm{Fe}_{2}(\mathrm{SR})_{2}(\mathrm{CO})_{4} \mathrm{~L}_{2}$ systems elongates the $\mathrm{Fe}-\mathrm{Fe}$ distance by only $0.05 \AA$. $^{7}$

The photoaddition of $\mathrm{H}_{2}$ is representative of a potentially general reaction whereby substrates oxidatively add to the diruthenium species with loss of CO. Photolysis of a toluene solution of $\mathbf{1}$ and HOTs $\left(\mathrm{HOSO}_{2} \mathrm{C}_{6} \mathrm{H}_{4} \mathrm{Me}\right)$ gave a single isomer of hydride $\mathrm{Ru}_{2^{-}}$ $\left(\mathrm{S}_{2} \mathrm{C}_{3} \mathrm{H}_{6}\right)(\mu-\mathrm{H})(\mathrm{OTs})(\mathrm{CO})_{3}\left(\mathrm{PCy}_{3}\right)_{2}(\mathbf{3 a})$ as assigned by ${ }^{1} \mathrm{H}$ and ${ }^{31} \mathrm{P}$ NMR measurements. Similar reactivity was observed for $\mathrm{HCl}$ and $\mathrm{HSPh}$ to give the corresponding chloro and thiophenolato complexes 3b and 3c. In the case of the HOTs reaction, IR and NMR measurements indicate that the conversion commences with (nonphotochemical) protonation of the $\mathrm{Ru}-\mathrm{Ru}$ bond to give $\left[\mathrm{Ru}_{2}\right.$ $\left.\left(\mathrm{S}_{2} \mathrm{C}_{3} \mathrm{H}_{6}\right)(\mu-\mathrm{H})(\mathrm{CO})_{4}\left(\mathrm{PCy}_{3}\right)_{2}\right] \mathrm{OTs}$. Photodissociation of $\mathrm{CO}$ from this cation permits coordination of the counteranion. Spectroscopic measurements indicate that the coordination geometries of $\mathbf{3 a}-\mathbf{3 c}$ 


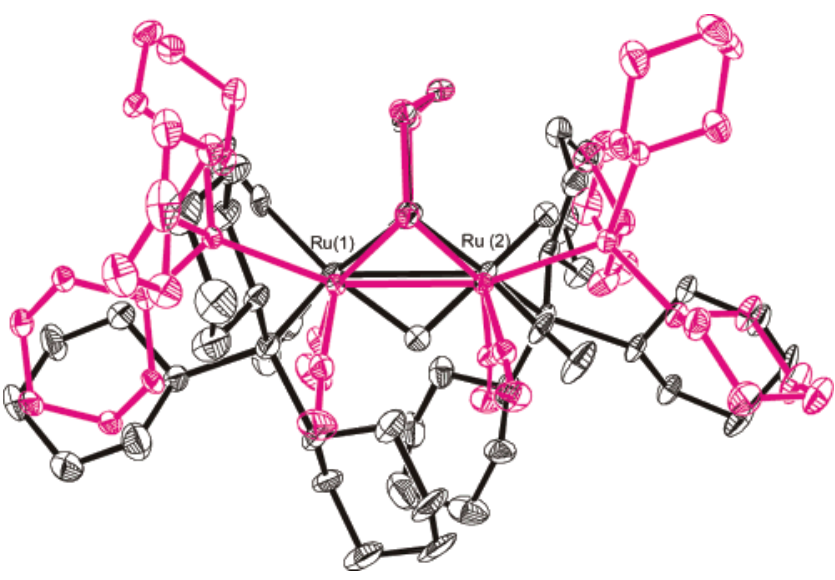

Figure 2. Molecular structures of $\mathrm{Ru}_{2}\left(\mathrm{~S}_{2} \mathrm{C}_{3} \mathrm{H}_{6}\right)(\mathrm{CO})_{4}\left(\mathrm{PCy}_{3}\right)_{2}$ (1) (magenta) and $\mathrm{Ru}_{2}\left(\mathrm{~S}_{2} \mathrm{C}_{3} \mathrm{H}_{6}\right)(\mu-\mathrm{H})(\mathrm{H})(\mathrm{CO})_{3}\left(\mathrm{PCy}_{3}\right)_{2}(2)$ (black) with thermal ellipsoids set at the $35 \%$ probability level. Solvate and $\mathrm{H}$ atoms were excluded for clarity; $\mathrm{Ru}-\mathrm{H}$ positions were refined. Selected distances $(\AA)$ and angles (deg) for $\mathbf{2}$ are as follows: $\mathrm{Ru}(1)-\mathrm{Ru}(2), 2.8970(9) ; \mathrm{Ru}(1)-\mathrm{H}(1), 2.01(3)$; $\mathrm{Ru}(2)-\mathrm{H}(1), 1.77(3) ; \mathrm{Ru}(2)-\mathrm{H}(2), 1.57(3) ; \mathrm{Ru}(1)-\mathrm{S}(1), 2.419(2) ; \mathrm{Ru}(1)-$ $\mathrm{S}(2), 2.415(2) ; \mathrm{Ru}(2)-\mathrm{S}(1), 2.4198(19) ; \mathrm{Ru}(2)-\mathrm{S}(2), 2.4193(18) ; \mathrm{Ru}(1)-$ $\mathrm{P}(1), 2.389(2) ; \mathrm{Ru}(2)-\mathrm{P}(2), 2.316(2) ; \mathrm{Ru}(1)-\mathrm{C}(40), 1.913(7) ; \mathrm{Ru}(1)-\mathrm{C}(41)$ 1.845(9); $\mathrm{Ru}(2)-\mathrm{C}(42), 1.854(7) ; \mathrm{Ru}(1)-\mathrm{S}(1)-\mathrm{Ru}(2), 73.55(6) ; \mathrm{Ru}(1)-$ $\mathrm{S}(2)-\mathrm{Ru}(2), 73.64(5) ; \mathrm{Ru}(2)-\mathrm{Ru}(1)-\mathrm{H}(1), 36.9(10) ; \mathrm{Ru}(1)-\mathrm{Ru}(2)-\mathrm{H}(1)$, 43.0(11); $\mathrm{Ru}(1)-\mathrm{Ru}(2)-\mathrm{H}(2), 135.7(17) ; \mathrm{H}(1)-\mathrm{Ru}(2)-\mathrm{H}(2), 178(2)$.

are analogous to that for $\mathbf{2}$. The structure of chloride $\mathbf{3 b}$ was confirmed crystallographically. Addition of $\mathrm{HCl}$ to $\mathbf{2}$ afforded $\mathbf{3 b}$ and $\mathrm{H}_{2}$.

Interesting results come from protonation experiments that probe the formation of the corresponding dihydrogen complex. Treatment of 2 with $\left[\mathrm{H}\left(\mathrm{OEt}_{2}\right)\right] \mathrm{BAr}_{4}{ }_{4}\left(\mathrm{Ar}^{\mathrm{F}}=\mathrm{C}_{6} \mathrm{H}_{3}-3,5-\left(\mathrm{CF}_{3}\right)_{2}\right)$ in acetone- $d_{6}$ solution $\left(25^{\circ} \mathrm{C}\right)$ resulted in the formation of free $\mathrm{H}_{2}$ and $\mathrm{HD}$, detected by ${ }^{1} \mathrm{H}$ NMR spectroscopy. Acetone is proposed to displace an incipiently formed $\mathrm{H}_{2}$ ligand, and the $\mathrm{HD}$ arises similarly but after the H/D exchange between $\left[\mathrm{H}\left(\mathrm{OEt}_{2}\right)\right] \mathrm{BAr}_{4}{ }_{4}$ and acetone- $d_{6}$. NMR data of the product are consistent with $\left[\mathrm{Ru}_{2}\left(\mathrm{~S}_{2} \mathrm{C}_{3} \mathrm{H}_{6}\right)(\mu-\mathrm{H})-\right.$ $\left.(\mathrm{CO})_{3}\left(\mathrm{PCy}_{3}\right)_{2}\left(\mathrm{OCMe}_{2}-d_{6}\right)\right]^{+} .{ }^{1} \mathrm{H}$ NMR analysis for the protonation of 2 in $\mathrm{CD}_{2} \mathrm{Cl}_{2}$ solution indicates formation of $\left[\mathrm{Ru}_{2}\left(\mathrm{~S}_{2} \mathrm{C}_{3} \mathrm{H}_{6}\right)(\mu\right.$ $\left.\mathrm{H})(\mathrm{CO})_{3}\left(\mathrm{PCy}_{3}\right)_{2}\left(\mathrm{H}_{2}\right)\right]^{+}(4$, Scheme 1). In particular, we observe a ${ }^{31} \mathrm{P}$-coupled triplet at $\delta-13.2$ and a broad singlet of intensity $2 \mathrm{H}$ at $\delta-5.9\left(T_{1}\right.$ at $\left.25{ }^{\circ} \mathrm{C}=30 \mathrm{~ms}, 11.7 \mathrm{~T}\right) .{ }^{1} \mathrm{H}$ NMR data for $4-d_{1}$, derived from the reaction of 2 with $\left[\mathrm{D}\left(\mathrm{OEt}_{2}\right)\right] \mathrm{BAr}^{\mathrm{F}}$ gave a triplet at $\delta-6.1$ with ${ }^{1} J_{\mathrm{H}-\mathrm{D}}$ of $31 \mathrm{~Hz}$, indicative of a $\mathrm{H}-\mathrm{D}$ distance of $0.90 \AA .{ }^{3}$ We observed no deuterium incorporation into the $\mu-\mathrm{H}$ ligand, even after several days at room temperature. Solutions of $\left[\mathrm{Ru}_{2}\left(\mathrm{~S}_{2} \mathrm{C}_{3} \mathrm{H}_{6}\right)(\mu-\mathrm{H})\left(\mathrm{H}_{2}\right)(\mathrm{CO})_{3}\left(\mathrm{PCy}_{3}\right)_{2}\right]^{+}$, which are stable for several days at room temperature, catalyze the exchange between $\mathrm{D}_{2}$ and $\mathrm{H}_{2}$, a characteristic reaction of hydrogenases. ${ }^{1,2}$

In summary, we report the following advances in hydrogenase modeling: (i) the first example of $\mathrm{H}_{2}$ addition to a hydrogenase model, (ii) demonstration that the terminal hydride is more hydridic than the bridging hydride, and (iii) first dihydrogen complex of a hydrogenase active site model. The $\mathrm{Ru}_{2}(\mathrm{SR})_{2}(\mathrm{CO})_{6-x} \mathrm{~L}_{x}$ complexes are sufficiently diverse and manipulable ${ }^{11,15}$ that it should be possible to prepare a range of hydride derivatives and probe their reactivity. We anticipate that these developments will guide the preparation of the corresponding diiron model systems and a fuller understanding of the underlying enzymology.

Acknowledgment. This research was supported by NIH. We thank Borislava Bekker for experimental assistance and Dr. Joshua Lawrence for reading the manuscript.

Supporting Information Available: Preparative details, spectroscopic data, and crystallographic analyses. This material is available free of charge via the Internet at http://pubs.acs.org.

\section{References}

(1) Frey, M. ChemBioChem 2002, 3, 153-160. Evans, D. J.; Pickett, C. J. Chem. Soc. Rev. 2003, 32, 268-275.

(2) Volbeda, A.; Fontecilla-Camps, J. C. Dalton Trans. 2003, 4030-4038.

(3) Kubas, G. J. Metal Dihydrogen and $\sigma$-Bond Complexes; Kluwer Academic/ Plenum Publishers: New York, 2001.

(4) Basic Research Needs for the Hydrogen Economy: Report of the Basic Energy Sciences Workshop on Hydrogen Production, Storage, and Use, May 13-15, 2003 (http://www.eere.energy.gov/hydrogenandfuelcells/pdfs/ bes_project.pdf). Cammack, R.; Frey, M.; Robson, R. Hydrogen as a Fuel: Learning from Nature; Taylor \& Francis: London, 2001.

(5) Peters, J. W.; Lanzilotta, W. N.; Lemon, B. J.; Seefeldt, L. C. Science 1998, 282, 1853-1858.

(6) Nicolet, Y.; de Lacey, A. L.; Vernede, X.; Fernandez, V. M.; Hatchikian, E. C.; Fontecilla-Camps, J. C. J. Am. Chem. Soc. 2001, 123, 1596-1601.

(7) Gloaguen, F.; Lawrence, J. D.; Rauchfuss, T. B.; Bénard, M.; Rohmer, M.-M. Inorg. Chem. 2002, 41, 6573-6582. Savariault, J.-M.; Bonnet, J.-J.; Mathieu, R.; Galy, J. C. R. Hebd. Seances Acad. Sci., Ser. C 1977 $284,663-665$

(8) Nehring, J. L.; Heinekey, D. M. Inorg. Chem. 2003, 42, 4288-4292.

(9) Gloaguen, F.; Lawrence, J. D.; Rauchfuss, T. B. J. Am. Chem. Soc. 2001 $123,9476-9477$.

(10) Zhao, X.; Georgakaki, I. P.; Miller, M. L.; Yarbrough, J. C.; Darensbourg, M. Y. J. Am. Chem. Soc. 2001, 123, 9710-9711.

(11) Cabeza, J. A.; Martinez-Garcia, M. A.; Riera, V.; Ardura, D.; GarciaGranda, S.; Van der Maelen, J. F. Eur. J. Inorg. Chem. 1999, 11331139.

(12) Hossain, G. M. G.; Hyder, M. I.; Kabir, S. E.; Abdul Malik, K. M.; Miah, M. A.; Siddiquee, T. A. Polyhedron 2003, 22, 633-640.

(13) Hampton, C. R. S. M.; Butler, I. R.; Cullen, W. R.; James, B. R.; Charland, J. P.; Simpson, J. Inorg. Chem. 1992, 31, 5509-5520.

(14) Chinn, M. S.; Heinekey, D. M. J. Am. Chem. Soc. 1990, 112, 51665175 .

(15) Shiu, K.-B.; Wang, S.-L.; Liao, F.-L.; Chiang, M. Y.; Peng, S.-M.; Lee, G.-H.; Wang, J.-C.; Liou, L.-S. Organometallics 1998, 17, 1790-1797. Cabeza, J. A.; Martinez-Garcia, M. A.; Riera, V.; Ardura, D.; GarciaGranda, S. Organometallics 1998, 17, 1471-1477. 